\title{
Front Matter: Volume 8735
}

, "Front Matter: Volume 8735," Proc. SPIE 8735, Head- and Helmet-Mounted Displays XVIII: Design and Applications, 873501 (21 May 2013); doi: $10.1117 / 12.2030338$

EPIE Event: SPIE Defense, Security, and Sensing, 2013, Baltimore, Maryland, SPIE. United States 


\section{PROCEEDINGS OF SPIE}

\section{Head- and Helmet-Mounted Displays XVIII: Design and Applications}

Peter L. Marasco

Paul R. Havig

Michael P. Browne

James E. Melzer

Editors

1 May 2013

Baltimore, Maryland, United States

Sponsored and Published by

SPIE 
The papers included in this volume were part of the technical conference cited on the cover and title page. Papers were selected and subject to review by the editors and conference program committee. Some conference presentations may not be available for publication. The papers published in these proceedings reflect the work and thoughts of the authors and are published herein as submitted. The publisher is not responsible for the validity of the information or for any outcomes resulting from reliance thereon.

Please use the following format to cite material from this book:

Author(s), "Title of Paper," in Head- and Helmet-Mounted Displays XVIII: Design and Applications, edited by Peter L. Marasco, Paul R. Havig, Michael P. Browne, James E. Melzer, Proceedings of SPIE Vol. 8735 (SPIE, Bellingham, WA, 2013) Article CID Number.

ISSN: 0277-786X

ISBN: 9780819495266

Published by

SPIE

P.O. Box 10, Bellingham, Washington 98227-0010 USA

Telephone +1 3606763290 (Pacific Time) · Fax +1 3606471445

SPIE.org

Copyright @ 2013, Society of Photo-Optical Instrumentation Engineers.

Copying of material in this book for internal or personal use, or for the internal or personal use of specific clients, beyond the fair use provisions granted by the U.S. Copyright Law is authorized by SPIE subject to payment of copying fees. The Transactional Reporting Service base fee for this volume is $\$ 18.00$ per article (or portion thereof), which should be paid directly to the Copyright Clearance Center (CCC), 222 Rosewood Drive, Danvers, MA 01923. Payment may also be made electronically through CCC Online at copyright.com. Other copying for republication, resale, advertising or promotion, or any form of systematic or multiple reproduction of any material in this book is prohibited except with permission in writing from the publisher. The CCC fee code is 0277-786X/13/\$18.00.

Printed in the United States of America.

Publication of record for individual papers is online in the SPIE Digital Library.

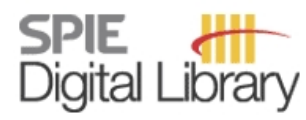

SPIEDigitalLibrary.org

Paper Numbering: Proceedings of SPIE follow an e-First publication model, with papers published first online and then in print and on CD-ROM. Papers are published as they are submitted and meet publication criteria. A unique, consistent, permanent citation identifier (CID) number is assigned to each article at the time of the first publication. Utilization of CIDs allows articles to be fully citable as soon as they are published online, and connects the same identifier to all online, print, and electronic versions of the publication. SPIE uses a six-digit CID article numbering system in which:

- The first four digits correspond to the SPIE volume number.

- The last two digits indicate publication order within the volume using a Base 36 numbering

system

employing both numerals and letters. These two-number sets start with $00,01,02,03,04,05,06$, $07,08,09,0 \mathrm{~A}, 0 \mathrm{~B} \ldots \mathrm{OZ}$, followed by 10-1Z, 20-2Z, etc.

The CID Number appears on each page of the manuscript. The complete citation is used on the first page, and an abbreviated version on subsequent pages. Numbers in the index correspond to the last two digits of the six-digit CID Number. 


\section{Contents}

$\checkmark$ Conference Committee

\section{SESSION $1 \quad$ HMD COMPONENTS}

873502 Scorpion hybrid optical-based inertial tracker (HObIT) [8735-1]

R. Atac, E. Foxlin, ThalesVisionix Inc. (United States)

873504 Novel method for characterization and compensation for canopy distortion over a large head box [8735-4]

R. Atac, M. Fischler, Thales Visionix Inc. (United States)

873505 Active matrix organic light emitting diode (AMOLED) performance and life test results [8735-5]

D. A. Fellowes, M. E. Botkin, R. S. Draper, U.S. Army Night Vision and Electronic Sensors Directorate (United States); J. Coletta, USSOCOM HQ (United States)

873506 Dynamic sunlight filter (DSF) for HMD: controlling background illumination in a passive way [8735-6]

A. Donval, N. Gross, E. Partouche, I. Dotan, O. Lipman, M. Oron, KiloLambda Technologies, Ltd. (Israel)

873507 Sampled MTF of fused fiber optic components and bonded assemblies [8735-18]

T. Carter, SCHOTT North America, Inc. (United States)

\section{SESSION 2 HUMAN FACTORS FOR HMDS}

873509 Insight into vergence/accommodation mismatch (Invited Paper) [8735-7]

M. S. Banks, J. Kim, Univ. of California, Berkeley (United States); T. Shibata, Tokyo Univ. of Social Welfare (Japan)

$87350 \mathrm{~A}$ Testing and evaluation of a wearable augmented reality system for natural outdoor environments [8735-11]

D. Roberts, A. Menozzi, J. Cook, T. Sherrill, S. Snarski, P. Russler, B. Clipp, R. Karl, E. Wenger, M. Bennett, J. Mauger, W. Church, H. Towles, S. MacCabe, J. Webb, J. Lupo, Applied Research Associates (United States); J.-M. Frahm, E. Dunn, C. Leslie, Univ. of North Carolina at Chapel Hill (United States); G. Welch, Univ. of Central Florida (United States) 
8735 OC Advancements in HMD technology: the DARPA-sponsored SCENICC program (Invited Paper) [8735-12]

R. Sprague, A. Zhang, S. Cookson, Innovega Inc. (United States); L. Hendricks, T. O'Brien, Rockwell Collins (United States); J. Ford, Univ. of California, San Diego (United States);

E. Tremblay, Ecole Polytechnique Fédérale de Lausanne (Switzerland); T. Rutherford,

D. Reinert, Greenlight Optics (United States); A. Johnson, Distant Focus (United States)

8735 OD HMD digital night vision system for fixed wing fighters [8735-13]

B. D. Foote, Rockwell Collins-ESA Vision Systems, LLC (United States)

8735 OF Optical see-through head-mounted display with occlusion capability [8735-15]

C. Gao, Y. Lin, H. Hua, Augmented Vision Inc. (United States)

Author Index 


\title{
Conference Committee
}

\author{
Symposium Chair
}

Kenneth R. Israel, Major General (USAF Retired) (United States)

Symposium Cochair

David A. Whelan, Boeing Defense, Space, and Security

(United States)

Conference Chairs

Peter L. Marasco, Air Force Research Laboratory (United States)

Paul R. Havig, Air Force Research Laboratory (United States)

Michael P. Browne, SA Photonics (United States)

James E. Melzer, Rockwell Collins Optronics (United States)

Conference Program Committee

Randall E. Bailey, NASA Langley Research Center (United States)

Sion Jennings, National Research Council Canada (Canada)

\section{Session Chairs}

1 HMD Components

James E. Melzer, Rockwell Collins Optronics (United States)

2 Human Factors for HMDs

James E. Melzer, Rockwell Collins Optronics (United States)

3 Systems Perspectives

Michael P. Browne, SA Photonics (United States) 
Proc. of SPIE Vol. $8735873501-6$

Downloaded From: https://www.spiedigitallibrary.org/conference-proceedings-of-spie on 26 Apr 2023 Terms of Use: https://www.spiedigitallibrary.org/terms-of-use 